\title{
Investigation of Factors Influencing Students' Intention to Use Banking Services through Smartphone Devices during COVID-19 Pandemic
}

\author{
Submitted 04/12/20, $1^{\text {st }}$ revision 28/01/21, $2^{\text {nd }}$ revision 09/02/21, accepted 20/03/21

\section{Chompu Nuangjamnong ${ }^{1}$}

\section{Abstract:}

Purpose: This research aims to Investigate factors Influencing students' intention to use banking services through smartphone devices during the COVID-19 pandemic. The conceptual framework is presented on the element of independent variables; perceived usefulness, perceived ease of use, relative advantage, and social influence factors Influencing students' intention and actual usage of banking services through smartphone devices during the COVID-19 pandemic.

Design/Methodology/Approach: The sample $(n=400)$ was collected from online questionnaires by using multi-stage sampling, including simple random sampling, stratified random sampling in probability sampling, and then non-probability sampling consist of convenience sampling and snowball sampling from graduate students of the top five private universities in the Bangkok metropolitan which approximately were 18,778 students. The study applied the data analysis method consisting of Cronbach's Alpha, descriptive statistics, simple linear regression (SLR), and multiple linear regression (MLR).

Findings: The results indicated the element of independent variables; perceived usefulness, perceived ease of use, and relative advantage have a significant influence on students, intention to use toward actual usage mobile banking services through smartphone devices during the COVID-19 pandemic except for one variable that has not supported which is social influence.

Practical Implications: Thus, the study recommends that the commercial banks and the universities as service providers should pay attention to expanding the internet access area for mobile banking services as universities' infrastructure. Universities recommended providing guidelines and appropriate training for using mobile banking services in clear steps, and commercial banks need to keep improving and upgrading their mobile banking services.

Originality/Value: This study identifies the value and degree of factors influencing students' intention to use banking services through smartphone devices during the COVID-19 pandemic.

Keywords: Perceived usefulness, perceived ease of use, relative advantage, social influence, student intention to use, actual usage, mobile banking services.

JEL Codes: H2, H21, J54, Q13.

Article Type: Research study.

${ }^{1}$ Lecturer, Innovative Technology Management, Graduate School of Business, Assumption University, Bangkok, Thailand, chompunng@au.edu 


\section{Introduction}

The rapid improvement in technology has challenged financial institutions to move from traditional banking to electronic banking. As commercial banks in the past five years ago provide services geographically to expand and capture the market share, customers need to go to branches or places that offer automated teller machines (ATM) for their banking transactions. Meanwhile, mobile banking services (MBS) are generally perceived as a form of electronic banking. Nowadays, there are many channels for a commercial bank to deliver the services for their customers. Customers can directly enter mobile banking services through their wireless and smart devices, known as mobile phones, to do their banking transactions. MBS offers customers to manage their bank account anytime and anywhere on their smart devices or a mobile phone, then customers can basically log into the mobile banking services in each commercial bank. These processes can save time and save transportation costs for customers to organize the transactions.

Using MBS, customers do not need to go to the bank branch to do their financial transactions anymore. MBS via smart devices is on-trend to grow rapidly in shortly future after finishing the COVID-19 pandemic. Even though the smart devices are easy to use and people can bring these devices almost everywhere, in concurrency, each commercial bank can provide customers with easy access to their financial account by using the application. Today, with the growth of the Internet, there are many necessary reasons for commercial banks to push smart technologies into their businesses to offer an online service. The advantage of going online is potential saving in the operation cost, maintenance cost in traditional businesses, and increasing customer base.

By definition, MBS are digital services offered by commercial banks and other financial institutions that permit their customers to proceed with financial transactions remotely using various smart devices such as a smartphone, laptop, notebook, or tablet. MBS is related to custom applications or software, normally called 'app = application" provided by commercial banks and financial institutions for their services' purpose. Moreover, MBS is normally available 24/7 basically. The study by Elhajjar and Ouaida (2019) revealed that the commercial banks had launched MBS that supports the customer to manage a financial transaction through mobile phones efficiently.

According to Akturan and Tezcan (2012), they confirmed that mobile banking applications provide numerous banking features include payments, check balance, account transactions, and access to financial information and services through mobile phones that customers can access from anywhere. Meanwhile, Singh (2014) described mobile banking as a mobility and delivery channel that can help banks deliver new electronic value services to customers, such as immediate access and additional personnel finances. According to Suchit (2019), "Thailand ranked No. 1 for internet users engaging in mobile banking, as well as time spent on game consoles, according to the Digital 2020 report. The report was published by „We are 
social Inc agency in partnership with social media solutions provider Hootsuite, focusing on digital, mobile, and social media trends worldwide. Regarding the use of banking and financial services apps, Thailand remained in the pole position among 46 countries in the report for the second year in a row."

Many universities have encouraged their students to use e-Payment via MBS to pay their fees to avoid universities' financial error transactions and human error. Furthermore, during 2020, COVID-19 Pandemic, also called Coronavirus disease, this disease has an outbreak in Wuhan, China, which spread to people more than 5.69 million. The COVID-19 disease has caused the most major disruption worldwide, then, most universities policies have been announced and encouraged regarding "social distancing" to try to minimize the epidemic of COVID-19 (The World Bank Group, 2020). Students in higher education, especially university students, have been involved with MBS, in particular e-Payment. Hence, there are massively contributing the efforts to provide alternative services through MBS instead of the traditional service platform for students, including digital financial transactions of a university. This study focuses on factors influencing students' intention to use mobile banking services through smart devices. Four independent variables are Perceived usefulness, perceived ease of use, social influence, and relative advantage, will be tested and discussed.

\section{Literature Review}

\subsection{Theory of Technology Acceptance Model (TAM)}

Technology Acceptance Model (TAM) is the most common and significant theory. Many research applies to identify the factors affecting the intention to use mobile banking services conducted, and a variety of those research was also based on the TAM in original created by Davis (1986). TAM is designed to describe the individual acceptance of technology and usage. TAM is a general model to explain the user's Information Technology (IT) adoption processes. This theory is commonly used to forecast user acceptance of IT, including MBS referring to Davis (1989). TAM contains two main components, perceived of usefulness (PU) and perceived ease of use (PEOU) relied on "Theory of Reasoned Action (TRA)" by Fishbein and Ajzen's (1975), which are also relevant keys for computer acceptance behavior, these two factors create a behavioral intention to use and use behavior after its use (Tobbin, 2012).

In this theory, users consider IT as useful when carrying out their work using information technology is high, and it is mentioned as perceived usefulness. As a result, perceived usefulness positively affects the user's intention to use a specific IT. In contrast, users would not use IT if it is difficult to use and it takes a lot of effort and time even thus, IT is perceived as useful. Therefore, PU and PEOU directly affect the attitude about IT and intention to use these technologies. TAM by Davis (1986) further described that PU plays a role of indirectly improving the 
intention to use if the IT is perceived as useful when the system is easy to use (Venkatesh et al., 2003; Hill et al., 1977; Davis, 1989; Fishbein and Ajzen, 1975).

Perceived usefulness (PU) is described as a degree from which beliefs in using a particular system would increase the performance of their jobs (Davis, 1989). Mobile banking services provide various services, including currency transfer, withdrawn money without using the card, e-Billing, e-Payment, managing loan and investment, e-Statement, issue a debit card, etc. These services can be complete via mobile banking services. This enables customers to reduce wasting time instead of going to branches. The perceived usefulness also includes performance increase, effectiveness, overall usefulness, time-saving, productivity increase, and increase job performance (Tobbin, 2012).

Perceived Ease of Use (PEOU) is defined as a degree to the person that beliefs in a particular system would be less or no effort to use (Davis, 1989). The difficulty of use is the barrier to people's consideration from changing. Moreover, it includes ease of control, clarity, and flexibility of use (Tobbin, 2012). Mobile banking services place the most used services such as money transfer, top-up, payment, and withdrawal in the home menu. Subsequent, other services menu that includes more categorize services in a simple arrangement. Mobile banking services are beneficial to consumers by reducing the effort from going to branches and face with the bank process's complexity. Then, the proposed model includes perceived usefulness and perceived ease of use; then, the following hypotheses are formed.

H1a: Perceived usefulness has a positive significant influence on student intention to use mobile banking services through smart devices.

HIb: Perceived ease of use has a positive significant influence on student intention to use mobile banking services through smart devices.

\subsection{Relative Advantage}

Definition of relative advantage (RA) is the degree to which an innovation is that individual perceived and has more advantage on usage than the previous one (Moore and Benbasat, 1991). Mobile banking services offer consumers an item from various official stores in Thailand. Customers can get an item by using the money or using a credit card point to redeem. Still, Mobile banking services also offer numerous privileges such as an in-game top-up bonus, insurance for COVID19 , and several promotions. Additionally, allow customers to customize the favorite services, changing background and payment slip to meet consumers' desires, which are increasingly using intention toward the application. Given the importance of student intention to use mobile banking services through smart devices, the model used in this study is a relative advantage; the following hypothesis is formed.

H1c: Relative advantage has a positive significant influence on student intention to use mobile banking services through smart devices. 


\subsection{Social Influence}

Social influence (SI), also known as social norms, defines how they should use the new system (Venkatesh, 2003). It can influence a person to believe that it can enhance their image or status in one's social system. Furthermore, social influence is founded to influence a person likely consider to acquire behavior accepted and selected by his/her important other or social peers (Farah et al., 2018). Social influence would influence people who are using another mobile banking service to consider changing or retain the existing consumer due to its ranked. Given the importance of student intention to use mobile banking services through smart devices, the model used in this study is social influence; the following hypothesis is formed.

H1d: Social influence has a positive significant influence on student intention to use e-Payment of mobile banking services through smart devices.

\subsection{Actual Usage}

The adoption of innovation frequently contains some changes in a consumer's lifestyle, e.g., their behavior is being shaped to fit new trends. The research by $\mathrm{Yu}$ (2012) described that a consumer's adoption intention is a vital area of education because they can forecast an individual's actual technology usage behavior. Moreover, adoption intentions demonstrate an individual's feeling and lead a possibility to execute a certain behavior, as illustrated by Jogiyanto (2007). Similarly, usage intentions outline consumer opinions and are believed to be a direct pattern to the actual behavior itself (Arahita and Hatammimi, 2015). Besides, use is the real criteria of using the system, which is evaluated as the amount of time used to interact with technology and the frequency of its use (Davis, 1989; Igbaria and Iivari, 1995). Indicators for measuring usage according to (Moon and Kim, 2001) are as follows: 1) Real use, 2) Use because of trust and reliability, and 3) Frequency of use $100 \%$. In this study, the researcher has established that actual usage is largely initiated by an individual's behavioral intentions (Hong et al., 2008; Venkatesh et al., 2012). Consequently, the researcher proposes the hypothesis as followed:

H2: Student intention to use e-Payment of mobile banking services through smart devices has a positive significant influence on actual usage.

\section{Research Methods and Materials}

\subsection{Research Framework}

Regarding to literature review shown on Figure 1, the conceptual framework is integration from theoretical of Technology Acceptance Model (TAM) and the chosen variables from related research. Each of variable are select by the research that has similarity dependent factor which is intention to use mobile banking and 
The literature review shown in Figure 1 shows that the conceptual framework is integrated from the theoretical of the Technology Acceptance Model (TAM) and the chosen variables from related research. Each variable is selected by the research that has a similarity dependent factor, which intends to use mobile banking and usage behavior. The chosen variable includes relative advantage and social influence.

\section{Figure 1. Conceptual Framework}

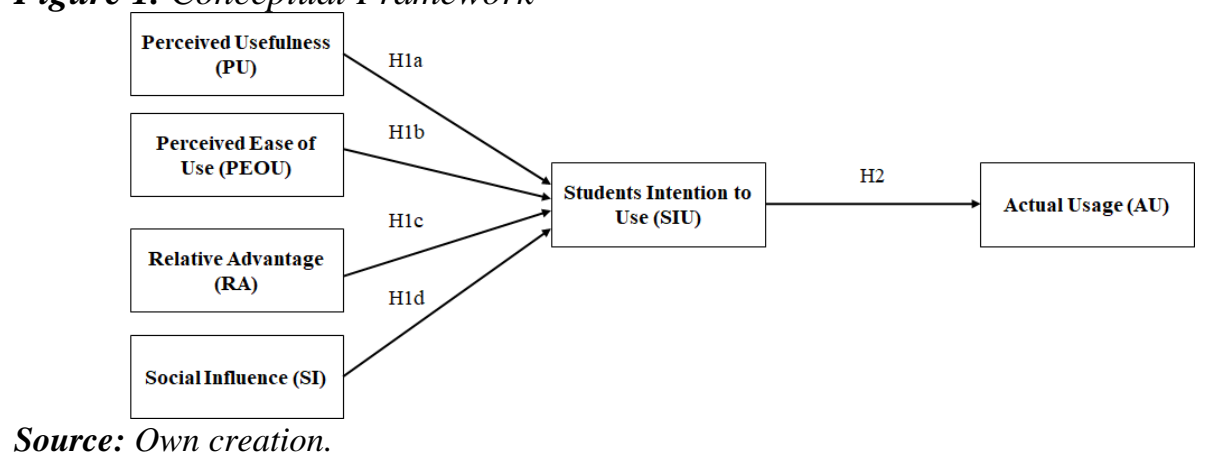

This study is proposed to determine the factors influencing students' intention to use mobile banking services through smart devices in Bangkok, Thailand. The variables are perceived usefulness (PU), perceived ease of use (PEOU), relative advantage (RA), social influence (SI), student intention to use (SIU), and actual usage (AU) among students in a private university in Thailand during COVID-19 pandemic. Furthermore, the research investigates the causal relationship between variables to reveal the effect of these factors affecting actual usage.

\subsection{Methodology}

Quantitative research will be used in this study. The target population is focused on graduate students in the top five private universities who live in Bangkok and using smart devices. These groups have been eligible to take responsibility for holding credit cards and have also been eligible to do an electronic transaction by themselves. The researcher applied probability sampling (simple random sampling by targeting graduate students in the top five private universities, Bangkok) and nonprobability sampling (convenient sampling using an online questionnaire with screening questions). The questionnaire was designed with 18 questions related to variables used using interval scale / Likert scale in five-points that respondents can rate from 1 (Strongly Disagree) to 5 (Strongly Agree).

The questionnaire was circulated thru an online questionnaire to the target group. The data analysis method consists of Cronbach's Alpha, descriptive statistics, simple linear regression (SLR), and multiple linear regression (MLR). For pilot testing, Cronbach's Alpha method was used to verify the reliability from 50 respondents, and index of item objective congruence (IOC) was also used to find the content validity by three experts; one in a commercial bank, one in the technology field, and another one in social science academic field. 


\subsection{Population and Sample Size}

The population used in this research consists of graduate students in private universities in the Bangkok Area (Office of the Permanent Secretary Ministry of Education, 2019) who have been enrolling the semester 1 and 2 in 2020 was 18,778 students. The researcher determined the right sample size based on the sample size table of Krejcie and Morgan (1970). The suitable number of samples for the 20,000 population is 377 people. The number of samples keeps decreasing with the increasing number of populations from the National Statistical Office source (2020). Therefore, the researcher assumes that 400 samples would be suitable for the 20,000 population.

\subsection{Sampling Technique}

In the first step, the researcher used simple random sampling in probability sampling, which means that every graduate student of the top five private universities in the Bangkok metropolitan has an equal probability of inclusion. Then adopted stratified random sampling of total graduate students of the top five private universities, which were 18,778 (Education Statistics by National Statistical Office) and were distributed by a ratio as shown in Table 1 . In the second step, the researcher established non-probability sampling by using convenience sampling. Then, the snowball sampling was carried out to select graduate students who study and live in Bangkok.

Table 1. Population and Sample Size by the top five private universities

\begin{tabular}{|l|c|c|}
\hline \multicolumn{1}{|c|}{ Top five private Universities } & $\begin{array}{c}\text { Number of Graduate } \\
\text { Students }\end{array}$ & $\begin{array}{c}\text { Sampl } \\
\text { e Size }\end{array}$ \\
\hline Assumption University & 5,470 & 117 \\
\hline Bangkok University & 5,681 & 121 \\
\hline Rangsit University & 3,623 & 77 \\
\hline $\begin{array}{l}\text { The University of Thai Chamber of } \\
\text { Commerce }\end{array}$ & 2,705 & 58 \\
\hline Mahanakorn University of Technology & 1,299 & 28 \\
\hline Total & $\mathbf{1 8 , 7 7 8}$ & $\mathbf{4 0 0}$ \\
\hline
\end{tabular}

Source: Office of the Permanent Secretary Ministry of Education (2019).

The questionnaire was distributed online only. The data collection had taken from

December 2019 to April 2020 during the COVID-19 pandemic situation. The data were screened to ensure that respondents met the target group of graduate students in the top five private universities. The online questionnaire was conveyed via social media, including Facebook, Email, Line Chat, Messenger, and private university contact points at the graduate school level. The respondents were encouraged to share the online questionnaire link among their friends who also met the required criteria. 


\section{Results and Discussion}

\subsection{Demographic Factors}

The demographic profile of the respondents of 400 respondents is summarized in Table 2. Most of the respondents were male, representing 44.5\%, whereas female respondents represented $55.5 \%$. In terms of age, the largest segment in this study $(58.5 \%)$ were less than 30 years old respondents; $32 \%$ of respondents were $31-40$ years old; $9.5 \%$ were over 41 years old. For the respondents' education, the majority was Master's degree, representing 71\%, whereas Doctorate's degree represented $29 \%$.

Table 2. Demographic Profile

\begin{tabular}{|c|l|c|c|}
\hline \multicolumn{2}{|c|}{ Demographic Data (N=400) } & Frequency & Percentage \\
\hline \multirow{2}{*}{ Gender } & Male & 178 & $44.5 \%$ \\
\cline { 2 - 4 } & Female & 222 & $55.5 \%$ \\
\hline \multirow{3}{*}{ Age } & Less than 30 years old & 234 & $58.5 \%$ \\
\cline { 2 - 4 } & $31-40$ years old & 128 & $32.0 \%$ \\
\cline { 2 - 4 } & More than 41 years old & 38 & $9.5 \%$ \\
\hline \multirow{2}{*}{ Education } & Master's degree & 409 & $71.0 \%$ \\
\cline { 2 - 4 } & Doctorate's degree & 28 & $29.0 \%$ \\
\hline
\end{tabular}

Source: Own creation.

\subsection{Descriptive Analysis with Mean and Standard Deviation}

This part showing the summary of Mean and Standard Deviation from each group of variables which are perceived usefulness (PU), perceived ease of use (PEOU), relative advantage (RA), social influence (SI), student intention to use (SIU), and actual usage (AU). The purpose is to find the average value from each group of variables illustrated in Table 3.

Table 3. The result of Mean and Standard Deviation

\begin{tabular}{|l|c|c|}
\cline { 2 - 3 } \multicolumn{1}{l|}{} & Mean & $\begin{array}{c}\text { Std. } \\
\text { Dev- } \\
\text { iatio } \\
\text { Perceived Usefulness (PU) }\end{array}$ \\
$\begin{array}{l}\text { PU1: Using mobile banking services would save my time, } \\
\text { during the COVID-19 pandemic. }\end{array}$ & 4.52 & .690 \\
$\begin{array}{l}\text { PU2: I would use mobile banking services anywhere, especially } \\
\text { during the COVID-19 pandemic. }\end{array}$ & 4.23 & .724 \\
$\begin{array}{l}\text { PU3: I would find mobile banking services is useful and major } \\
\text { channel do the financial transaction during the COVID-19 } \\
\text { pandemic. }\end{array}$ & 4.37 & .727 \\
\hline $\begin{array}{l}\text { Perceived Ease of Use (PEOU) } \\
\text { PEOU1: During the COVID-19 pandemic, I found that learning } \\
\text { to use mobile banking services is easy for me. }\end{array}$ & 4.41 & .730 \\
\hline
\end{tabular}




\begin{tabular}{|c|c|c|}
\hline $\begin{array}{l}\text { PEOU2: During the COVID-19 pandemic, I found that interact } \\
\text { with mobile banking services is easy for me. } \\
\text { PEOU3: During the COVID-19 pandemic, I found that mobile } \\
\text { banking services are easy to use and convenient to do a } \\
\text { financial transaction. }\end{array}$ & 4.28 & .694 \\
\hline $\begin{array}{l}\text { Relative Advantage (RA) } \\
\text { RA1: During the COVID-19 pandemic, I found that using } \\
\text { mobile banking services has more advantages to me. } \\
\text { RA2: During the COVID-19 pandemic, I found that using } \\
\text { mobile banking services offers me a better promotion e.g. no } \\
\text { fees, extra points, reward programs. } \\
\text { RA3: During the COVID-19 pandemic, I found that mobile } \\
\text { banking services offers me personalized services. }\end{array}$ & $\begin{array}{l}4.36 \\
4.26 \\
4.34\end{array}$ & $\begin{array}{l}.760 \\
.911 \\
.749\end{array}$ \\
\hline $\begin{array}{l}\text { Social Influence (SI) } \\
\text { SI1: People who are important to me encourage that I should } \\
\text { use mobile banking services e.g. family, partner, a close friend, } \\
\text { and my classmate, during the COVID-19 pandemic. } \\
\text { SI2: Acquainted people with me suggest that I should use } \\
\text { mobile banking services e.g. colleagues, my supervisor, and } \\
\text { faculty staff, during the COVID-19 pandemic. } \\
\text { SI3: People surrounding with me using mobile banking } \\
\text { services, during the COVID-19 pandemic. }\end{array}$ & $\begin{array}{l}4.25 \\
4.29 \\
4.38\end{array}$ & $\begin{array}{l}.849 \\
.861 \\
.719\end{array}$ \\
\hline $\begin{array}{l}\text { Students Intention to Use (SIU) } \\
\text { SIU1: I intend to use mobile banking services for my financial } \\
\text { transaction, during the COVID-19 pandemic. } \\
\text { SIU2: I would continue using mobile banking services in the } \\
\text { future after the COVID-19 pandemic has gone. } \\
\text { SIU3: I will always use mobile banking services in my daily } \\
\text { life. }\end{array}$ & $\begin{array}{l}4.41 \\
4.38\end{array}$ & $\begin{array}{l}.684 \\
.727 \\
.753\end{array}$ \\
\hline $\begin{array}{l}\text { Actual Usage (AU) } \\
\text { AU1: During the COVID-19 pandemic, I found that I actually } \\
\text { frequently use mobile banking services. } \\
\text { AU2: During the COVID-19 pandemic, I found that I also } \\
\text { recommend other people to use mobile banking services. } \\
\text { AU3: During the COVID- } 19 \text { pandemic, I found that it is worth } \\
\text { it for me to use mobile banking services. }\end{array}$ & $\begin{array}{l}4.35 \\
4.33 \\
4.48\end{array}$ & $\begin{array}{l}.723 \\
.779\end{array}$ \\
\hline
\end{tabular}

\section{Source: Own creation.}

Perceived Usefulness (PU) in Table 3; the most effective mean for perceived usefulness is "Using mobile banking services would save my time, during the COVID-19 pandemic." with a score of 4.52. Following the lowest "I would use mobile banking services anywhere, especially during the COVID-19 pandemic." with a score of 4.23. Meanwhile, the highest Standard Deviation is "I would find mobile banking services is useful, and major channel does the financial transaction during the COVID-19 pandemic" with a score of 0.727. Following the lowest "Using mobile banking services would save my time, during the COVID-19 pandemic." with a score of 0.690 .

Perceived Ease of Use (PEOU) in Table 3; the most effective mean for perceived ease of use is "During the COVID-19 pandemic, I found that mobile banking services are easy to use and convenient to do a financial transaction." with a score of 4.43. Following the lowest "During the COVID-19 pandemic, I found that interact 
with mobile banking services is easy for me." with a score of 4.28. Meanwhile, the highest Standard Deviation is "During the COVID-19 pandemic, I found that interact with mobile banking services is easy for me." with a score of 0.733 . Following the lowest "During the COVID-19 pandemic, I found that mobile banking services are easy to use and convenient to do a financial transaction." with a score of 0.694 .

Relative Advantage (RA) in Table 3; the most effective mean for perceived ease of use is "During the COVID-19 pandemic, I found that using mobile banking services has more advantages to me." with a score of 4.36. Following the lowest "During the COVID-19 pandemic, I found that using mobile banking services offers me a better promotion, e.g., no fees, extra points, reward programs." with a score of 4.26. Meanwhile, the highest Standard Deviation is "During the COVID-19 pandemic, I found that using mobile banking services offers me a better promotion, e.g., no fees, extra points, reward programs." with a score of 0.911 . Following the lowest "During the COVID-19 pandemic, I found that mobile banking services offer me personalized services." with a score of 0.749 .

Social Influence (SI) in Table 3; The most effective mean for perceived ease of use is "People surrounding with me using mobile banking services, during the COVID19 pandemic." with a score of 4.38. Following the lowest "People who are important to me encourage that I should use mobile banking services, e.g., family, partner, a close friend, and my classmate, during the COVID-19 pandemic." with a score of 4.25. Meanwhile, the highest Standard Deviation is "Acquainted people with me suggest that I should use mobile banking services, e.g., colleagues, my supervisor, and faculty staff, during the COVID-19 pandemic." with a score of 0.861. Following the lowest "People surrounding with me using mobile banking services, during the COVID-19 pandemic." with a score of 0.719 .

Student Intention to Use (SIU) in Table 3; the most effective mean for perceived ease of use is "I intend to use mobile banking services for my financial transaction, during the COVID-19 pandemic." with a score of 4.45. Following the lowest "I will always use mobile banking services in my daily life." with a score of 4.38. Meanwhile, the highest Standard Deviation is "I will always use mobile banking services in my daily life." with a score of 0.753 . Following the lowest "I intend to use mobile banking services for my financial transaction, during the COVID-19 pandemic." with a score of 0.684 .

Actual Usage (AU) in Table 3; the most effective mean for perceived ease of use is "During the COVID-19 pandemic, I found that it is worth for me to use mobile banking services." with a score of 4.48. Following the lowest "During the COVID19 pandemic, I found that I also recommend other people to use mobile banking services." with a score of 4.33. Meanwhile, the highest Standard Deviation is "During the COVID-19 pandemic, I found that I also recommend other people to use mobile banking services." with a score of 0.779 . Following the lowest "During 
the COVID-19 pandemic, I found that it is worth it for me to use mobile banking services." with a score of 0.704 .

\subsection{Multiple Linear Regression and Simple Linear Regression Analysis}

Multiple Linear Regression Analysis (MLR) for variables predicting presented in Table 4, all of the variables have VIF less than 5, which means it has no multicollinearity problem for this research. Perceived ease of use (PEOU) has a significant level of 0.000 which means the null hypothesis has been rejected as it less than 0.05. As a result, this will be concluded that perceived ease of use (PEOU) significantly influences a student's intention to use (SIU) mobile banking services.

The standardized coefficient of 0.200 can imply that if perceived ease of use (PEOU) increases by 1 percent, it will increase a student's intention to use (SIU) by 20 percent. Next, perceived usefulness (PU) has a significant level of 0.000 which means the null hypothesis has been rejected as it less than 0.05 . As a result, this will be concluded that perceived usefulness (PU) significantly influences a student's intention to use (SIU) mobile banking services. The standardized coefficient of 0.273 can imply that if perceived usefulness (PU) increases by 1 percent, it will increase a student's intention to use (SIU) by 27.3 percent. Then, relative advantage (RA) has a significant level of 0.000 which means the null hypothesis has been rejected as it less than 0.05 . As a result, this will be concluded that relative advantage (RA) is a significant influence on a significant influence on a student's intention to use (SIU) mobile banking services.

The standardized coefficient of 0.385 can imply that if relative advantage (RA) is increased by 1 percent, it will increase student's intention to use (SIU) by 38.5 percent. Lastly, social influence (SI) has a significant level of 0.586 which means the null hypothesis is failed to reject. It can describe that social influence (SI) has not supported the influence factor on a student's intention to use (SIU) mobile banking services in this study.

Table 4. Multiple Linear Regression Analysis for Variables Predicting

\begin{tabular}{|l|c|c|c|c|c|}
\hline \multicolumn{1}{|c|}{ Variables } & B & Std. Error & Beta & Sig. & VIF \\
\hline $\begin{array}{l}\text { Perceived Ease of Use } \\
\text { (PEOU) }\end{array}$ & .190 & .044 & .200 & $.000^{*}$ & 1.555 \\
\hline Perceived Usefulness (PU) & .275 & .044 & .273 & $.000^{*}$ & 1.379 \\
\hline Relative Advantage (RA) & .311 & .041 & .385 & $.000^{*}$ & 1.865 \\
\hline Social Influence (SI) & -.022 & .040 & -.027 & .586 & 1.766 \\
\hline
\end{tabular}

Note: $R^{2}=.679$, Adjusted $R^{2}=.462,{ }^{*} p<0.05$. Dependent Variable $=$ Student Intention to Use (SIU)

Source: Own creation.

The summary of Simple Linear Regression Analysis (SLR) for variable predicting is presented in Table 5; the variable has VIF less than 5, which means it has no multicollinearity problem for this study. Actual usage (AU) from Table 5 has a 
significant level of 0.000 which means the null hypothesis has been rejected as it less than 0.05; this will be concluded that a student's intention to use (SIU) is a significant influence on actual usage (AU) toward mobile banking services. The standardized coefficient of 0.598 can imply that if a student's intention to use (SIU) is increased by 1 percent, it will increase actual usage (AU) by 59.8 percent.

Table 5. Simple Linear Regression Analysis for Variable Predicting

\begin{tabular}{|c|c|c|c|c|c|}
\hline \multicolumn{1}{|c|}{ Variables } & B & $\begin{array}{c}\text { Std. } \\
\text { Error }\end{array}$ & Beta & Sig. & VIF \\
\hline Actual Usage (AU) & .635 & .043 & .598 & $.000^{*}$ & 1.00 \\
\hline
\end{tabular}

Note. $R^{2}=.598$, Adjusted $R^{2}=.356,{ }^{*} p<0.05$. Dependent Variable $=$ Actual Usage $(A U)$

Source: Own creation.

\subsection{Research Hypothesis Testing Result}

The significance of each variable in the research model is assessed from regression weights by multiple linear regression and simple linear regression, and r-squared variance coefficient. The result from Table 6 claimed that all hypotheses were supported with a significance at $\mathrm{p}=0.05$ except for social influence (SA) has been failed to reject the null hypothesis (H1d), as shown in Table 6.

Table 6. Hypothesis Result

\begin{tabular}{|l|c|c|c|}
\hline \multicolumn{1}{|c|}{ Hypotheses } & $\begin{array}{c}\text { Significant } \\
\text { Value }\end{array}$ & $\begin{array}{c}\text { Standardized } \\
\text { Coefficient }\end{array}$ & Status \\
\hline H1a: PEOU $\rightarrow$ SIU & $.000^{*}$ & .200 & Rejected \\
\hline H1b: PU $\rightarrow$ SIU & $.000^{*}$ & .273 & Rejected \\
\hline H1c: RA $\rightarrow$ SIU & $.000^{*}$ & .385 & Rejected \\
\hline H1d: SI $\rightarrow$ SIU & .586 & -.027 & $\begin{array}{c}\text { Failed to } \\
\text { Reject }\end{array}$ \\
\hline H2: SIU $\rightarrow$ AU & $.000^{*}$ & .598 & Rejected \\
\hline
\end{tabular}

Note. $*_{p}<0.05$.

Source: Own creation.

Table 7 described the variable's ranking from the most substantial influence to the weakest influence of independent variables to students' intention to use (SIU) mobile banking services through smart devices. An average of the beta was used to define the degree of influence of each variable. An average of the beta was 0.286 , which can be implied that the variable with a beta less than 0.286 is illustrated as the weak influential variable. On the other hand, the variable with a beta of more than 0.286 will be illustrated as the most substantial influential factor for students' intention to use mobile banking services through smart devices. There are some variables higher than 0.286 , which is the relative advantage (RA) of 0.385 . In contrast, there are two variables that a beta of less than 0.286 , which are perceived usefulness (PU) of 0.273 and perceived ease of use (PEOU) of .200 that can be 
concluded these variables had the lowest influence on students' intention to use mobile banking services through smart devices.

Table 7. Strength of influence of variable toward student intention to use (SIU)

\begin{tabular}{|c|c|c|}
\hline Rank & Independence Variable & Beta \\
\hline $1^{\text {st }}$ & Relative Advantage (RA) & .385 \\
\hline $2^{\text {nd }}$ & Perceived usefulness (PU) & .273 \\
\hline $3^{\text {rd }}$ & Perceived ease of use (PEOU) & .200 \\
\hline
\end{tabular}

Note: Dependent variable: Student Intention to Use (SIU).

Soure: Oen creation,

\section{Conclusions and Recommendation}

\subsection{Conclusion}

An investigation of factors influencing students' intention to use mobile banking services through smart devices has been emphasized and conducted to study during the COVID-19 pandemic in this research. The hypotheses were developed as the conceptual framework to examine which factors have influenced students' intention to use mobile banking services through smart devices in the graduate school of the top five private universities in Bangkok, Thailand. Three variables significantly influence a student's intention to use mobile banking services: perceived usefulness, perceived ease of use, and relative advantage. However, one variable has not supported factors influencing students' intention to use mobile banking services through smart devices, which is social influence. The research explicated the following outcomes.

Perceived usefulness was revealed that this variable influences students' intention to use mobile banking services through smart devices during the COVID-19 pandemic. The independent variable has been supported by the study of Ulun and Nuray (2012), which confirmed that perceived usefulness could support the principle concept of the advantages of using the application and making banking transactions via mobile devices easier. When the consumer perceives that mobile banking application is quicker and easier to do banking tasks, this will create a positive attitude toward mobile banking application.

Perceived ease of use was exposed that this variable influences students' intention to use mobile banking services through smart devices during the COVID-19 pandemic. According to the study by researchers (Lara et al., 2019), they illustrated that perceived ease of use is related to the convenience and the effortlessness to use in banking applications thru mobile devices. They also revealed that when the consumer perceived that the banking applications through mobile devices are easy to use or fewer efforts, they will slightly increase the positive perception of using the banking applications through mobile devices. 
Relative advantage, this independent variable was presented to influence students' intention to use mobile banking services through smart devices during the COVID19 pandemic. The previous study by Charles (2017) described that when the consumer found that banking applications via mobile devices are more beneficial than traditional banking, they also found a positive use of intention toward banking applications via mobile devices. Students' intention to use and actual usage was revealed that students' intention to use mobile banking services through smart devices during the COVID-19 pandemic influences actual usage.

Lastly, in this study, social influence does not influence students' intention to use mobile banking services through smart devices during the COVID-19 pandemic. This is because, during the COVID-19, the Thai Government encourage people to keep social distancing. Then all the social activities in the public area do not allow access to this, including the universities. With this rule and regulation, people intend to do their online activities. In this situation, we can be concluded that social influence will not influence students' intention to use mobile banking services through smart devices during the COVID-19 pandemic.

\subsection{Recommendation}

The coronavirus outbreak has created chaos and chaos on every side of the world. The researcher admits silent that the outbreak of the virus is severe, rapid, and widespread. Society will enter the fully digital system. The COVID-19 crisis created a major turning point for online technology such as e-commerce, financial, and educational industries. Because people avoid infection from public spaces and do all activities online more, in this study, the findings revealed that three variables significantly influence students' intention to use mobile banking services through smart devices during the COVID-19 pandemic. Therefore, the researcher recommended expanding the range of internet access to cover all the areas. This recommendation was taken from the lowest mean (4.23) of perceived usefulness (PU) in the survey when asking about "I would use mobile banking services anywhere, especially during the COVID-19 pandemic.

Next recommendation, the researcher recommended that the commercial banks and private universities encourage students to do electronic transactions more. For universities, they should provide guidelines and appropriate training for using mobile banking services in clear steps, and commercial banks need to keep improving and upgrading their mobile banking services. This recommendation was taken from the lowest mean (4.28) of perceived ease of use (PEOU) on the survey "During the COVID-19 pandemic; I found that interact with mobile banking services is easy for me."

Last recommendation, the researcher recommended that the commercial banks and university create a marketing campaign targeting students in the university, such as earning a reward program for free coffee or soft drink. This reward program can be supported by the relative advantage of students' intention to use mobile banking 
services through their own smart devices. This recommendation was taken from the lowest mean (4.26) of relative advantage "During the COVID-19 pandemic, I found that using mobile banking services offers me a better promotion, e.g., no fees, extra points, reward programs."

\subsection{Limitation and Further Study}

This study has limitations that should be investigated more for future researches. This research only focuses on graduate students in the top five private universities in Bangkok, Thailand, during the COVID-19 pandemic. The different schemes probably present different outcomes, e.g., public universities, universities' size, district, university payment policy, etc. Future studies may explore sample more in another geographical region to investigate any similar or different findings. The extended study can include the variables to investigate mobile payment attitude such as trust, security, privacy, etc.

\section{References:}

Akturan, U., Tezcan, N. 2012. Mobile banking adoption of the youth market: Perceptions and intentions. Marketing Intelligence and Planning, 30(4), 444-459. https://doi.org/10.1108/02634501211231928.

Arahita, C.L., Hatammimi, J. 2015. Factors affecting the intention to reuse mobile banking service. International Journal of Research in Business and Social Science, 4(4), 15-22.

Charles, M. 2017. Determinants of consumers' intention to adopt mobile banking services in Zimbabwe. International Journal of Bank Marketing, 35(6), 997-1017. https://doi.org/10.1108/IJBM-07-2016-0099.

Davis, F.D. 1986. A Technology Acceptance Model for Empirically Testing New End-User Information Systems: Theory and Results. Massachusetts Institute of Technology.

Davis, F.D. 1989. Perceived Usefulness, Perceived Ease of Use and User Acceptance of Information Technology. MIS Quarterly, 13(3), 319-340.

Elhajjar, S., Ouaida, F. 2019. An analysis of factors affecting mobile banking adoption. International Journal of Bank Marketing, 38(2), 352-367. https://doi.org/10.1108/IJBM-02-2019-0055.

Farah, M.F., Hasni, M.J.S., Abbas, A.K. 2018. Mobile-banking adoption: empirical evidence from the banking sector in Pakistan. International Journal of Bank Marketing, 36(7), 1386-1413. https://doi.org/10.1108/IJBM-10-2017-0215.

Fishbein, M., Ajzen, I. 1975. Belief, Attitude, Intention and Behavior: An Introduction to Theory and Research. Addison-Wesley Publishing Company.

Hill, R.J., Fishbein, M., Ajzen, I. 1977. Belief, Attitude, Intention and Behavior: An Introduction to Theory and Research. Contemporary Sociology, 6(2), 244. https://doi.org/10.2307/2065853.

Hong, S., Kim, J., Lee, H. 2008. Antecedents of use-continuance in information systems: toward an integrative view. The Journal of Computer Information Systems, 48(3), 61-73.

Igbaria, M., Iivari, J. 1995. The effects of self-efficacy on computer usage. Omega, 23(6), 587-605. https://doi.org/https://doi.org/10.1016/0305-0483(95)00035-6.

Jogiyanto, H.M. 2007. Sistem Informasi Keprilakuan. AndiPublisher. 
Krejcie, R.V., Morgan, D.W. 1970. Determining Sample Size for Research Actvities. Educational and Psychological Measurement, 30, 607-610.

Lara, S., Nina, M., Milena, M. 2019. Drivers and outcomes of branded mobile app usage intention. Journal of Product \& Brand Management, 28(1), 28-49. https://doi.org/10.1108/JPBM-02-2017-1436.

Moon, J.M., Kim, Y.G. 2001. Extending the TAM for a world-wide-web context. Information \& Management, 28, 217-30.

Moore, G.C., Benbasat, I. 1991. Development of an Instrument to Measure the Perceptions of Adopting an Information Technology Innovation. Information Systems Research, 2, 192-222.

National Statistical Office. 2020. Education Statistics: Students, Teachers, Institutions. National Statistical Office. http://statbbi.nso.go.th/staticreport/page/sector/en/03.aspx.

Office of the Permanent Secretary Ministry of Education. 2019. Number of students in the school system In government and private educational establishments Classified by educational level and academic year 2014-2018. National Statistical Office. http://statbbi.nso.go.th/staticreport/page/sector/th/03.aspx.

Singh, S. 2014. Customer Perception of Mobile Banking: An Empirical Study in National Capital Region Delhi. Journal of Internet Banking and Commerce, 19(3), 1-22. https://www.icommercecentral.com/open-access/customer-perception-of-mobilebanking-an-empirical-study-in-national-capital-region-delhi.php?aid=38010.

Suchit, L.N. 2019. Thais lead in mobile banking, gaming. Business section. Bangkok Post. https://www.bangkokpost.com/business/1849719/thais-lead-in-mobile-bankinggaming.

The World Bank Group. 2020. COVID-19 (Coronavirus) Policy Response on Facilitating the Use of Digital Payments in Russia. Worldbank.Org. https://www.worldbank.org/en/country/russia/brief/covid-19-response-digitalpayments-russia.

Tobbin, P. 2012. Towards a model of adoption in mobile banking by the unbanked: A qualitative study. Info, 14(5), 74-88. https://doi.org/10.1108/14636691211256313.

Ulun, A., Nuray, T. 2012. Mobile banking adoption of the youth market: Perceptions and intentions. Marketing Intelligence \& Planning, 30(4), 444-459. https://doi.org/10.1108/02634501211231928.

Venkatesh, V. 2003. User acceptance of Information Technology: Toward a Unified View. MIS Quarterly, 27, 425-478.

Venkatesh, V., Morris, M.G., Davis, G.B., Davis, F.D. 2003. User acceptance of information technology: Toward a unified view. MIS Quarterly, 27(3), 425-478. https://doi.org/10.2307/30036540.

Venkatesh, V., Thong, J.Y., Xu, X. 2012. Consumer acceptance and use of information technology: extending the unified theory of acceptance and use of technology. MIS Quarterly, 36(1), 157-178.

Yu, C.S. 2012. Factors affecting individuals to adopt mobile banking: empirical evidence from the UTAUT model. Journal of Electronic Commerce Research, 13(2), 104121. 